\title{
SELF ORGANISATION AS A TOOL FOR DIAGNOSIS OF INNOVATIVE ECOSYSTEM
}

\author{
Anna Yu. Yakovleva \\ Teacher Assistant at State University Higher School of Economics, Faculty of \\ Management, Depatment of Project Management, Moscow. \\ $\mathrm{PhD}$ at Russian Economic Academy. \\ anna@iustas.com
}

\begin{abstract}
Several studies have been conducted to identify innovative mechanisms for the successful development of various innovative regions. The scope of the current research is to shed light on this issue, taking into account the theory of self-organized systems and the principal properties of freescale networks. Using Silicon Valley as an example, the author demonstrated the majority of selforganized systems, thus determining what traits, working principles and laws should be available for use in innovative system. Self-organization as a key characteristic of an innovation ecosystem coupled with prerequisites, supports the growth of Silicon Valley and would be recommended as a model to be utilised in countries and regions across the world.
\end{abstract}

Key-words: Innovative mechanisms; Self-organized systems; Innovative system. 


\section{INTRODUCTION}

There is a current interest in innovation worldwide. Innovation has become a key advantage for countries, regions, and all type of companies. To facilitate the innovation development, governments, local authorities and executives of corporations try to stimulate innovation in products, process and in business itself to profit on it. In the effort to create and commercialize innovation, one of the approaches is to integrate and create links between science and businesses, by forming National (Regional, or Sectorial, etc.) Innovation Systems (NIS).

NIS functions include the following:

- development of special institutes, which provide regulatory functions;

- creation of innovative infrastructure;

- government work;

- coordinating educational and scientific activity by providing finance etc.

Usually state supports NIS by:

- preferential taxation

- direct financing

- allowance of loans

- creation of venture funds

- facilitating the process of the venture funds' creation etc.

Looking at the practice of stimulating innovation systems, government efforts occasionally lead to the consolidation of such systems, e. g. Finland and Israel. However, this is not always the case, e. g., Sophia Antipolis - France. In the case of Silicon Valley, however, the state didn't plan to create a NIS, or a RIS, but the system where innovation was naturally stimulated was nurtured and grew more steadily. Thus, there is no obvious single formula for building innovation systems, and is dependent upon the set of special conditions and prerequisites that allow innovation systems to work successfully. 
So, the core idea of this paper could be stated as:

- whether NIS is the best mean for innovation development

- which stakeholders make a region innovative and attract new enterprises

- if NIS fails to stimulate the region's innovativeness, or if the state fails to create a NIS (RIS), despite other innovations being successful in a region, which principles and laws regulate the process of prosperous innovation development?

\section{THEORETICAL FRAMEWORK}

NIS is currently an effective method of research. While the debate over this topic appears to gain popularity, certain vital aspects of NIS are omitted. The research in the problem area was undertaken by separate scholars, but the term "NIS" was coined by Freeman $(1987$, p. 1), who defined it as "...the network of institutions in the public and private sectors whose activities and interactions initiate, import, modify and diffuse new technologies". Consequently, experts on this issue, such as Lundval (1992) and Metcalfe (1995), extended the term by the submission of more advanced definitions: “...the elements and relationships which interact in the production, diffusion and use of new, and economically useful, knowledge ... and are either located within or rooted inside the borders of a nation state" (Lundvall, 1992, p. 2 ).

...that set of distinct institutions which jointly and individually contribute to the development and diffusion of new technologies and which provides the framework within which governments form and implement policies to influence the innovation process. As such it is a system of interconnected institutions to create, store and transfer the knowledge, skills and artefacts which define new technologies" (Metcalfe, 1995, p. 285).

Following on from the definition, both authors included in the definition the "use of new, and economically useful, knowledge... inside the borders of a nation state" (Lundvall, 1992, p. 2), giving more precise information about the government role to "form and implement policies to influence the innovation process" (Metcalfe, 1995, p. 285).

Previously, we considered theoretical aspects of NIS in Yakovleva (2009). Therefore, we now summarize them. Relating to the creation of NIS's top-down approach, used to form such a system: in our minds, this approach does not entirely satisfy the needs of all innovation system agents - it can not

Revista de Administração e Inovação, São Paulo, v. 7, n. 3, p. 03-20, jul./set. 2010 
consider in detail all aspects of element activity. To permit the innovation process in a country, region etc., we should alter the angle of approach a little.

Recently, the opposite approach, bottom-up, became wide-spread among practitioners. Innovation ecosystem, such as a resultant category of bottom-up approach is also widespread in innovating communities.

It is difficult to evaluate the extraordinary importance of Moore's (1997) contribution to studying the competition under the strategic management view. Moore was the first scholar to coin the term ecosystem and apply it to the economy. His core idea was alteration the way of traditional competition head-on for coexistence. He insists that cooperation will help a company compete effectively and procur new markets. The stages of entrepreneurial ecosystem were also illustrated by a case study for Wal-Mart.

Before Moore's study, the transfer of biological laws was completed by supporters of neoevolutionary theory in economy (Arthur, 1989, 1994; David, 1985; Hayek, 1992; Nelson, 1993). Said scholars researched the similarities between biology and economy, and defined that many economic phenomena follow biological laws, i.e. mutation, coexistence, adaptation, diversity of species etc.

Speaking about the usage of ecosystem as a term in economy, we should make a mention of Van der Bergh (2003) and Ayres (2004). The former investigated the commonality between mutation, genetic clones, competition, adaptation etc. in biology and economy. The latter studied common features between the two sciences. However, their field of research also included enterprise activity, concerning similarities amongst patterns of life of certain biological organisms. As with Ayres (2004), Moore (1997) considered ecosystem in economy, yet his research dealt with the creation of innovation ecosystem as a kind of platform for innovative production, including new items and its complements.

Another direction of research ecosystems in economy is presented by Briscoe and De Wilde (2009). Their field of study was digital ecosystems. Said authors define the term "ecosystems" as:

novel optimisation technique where the optimisation works at two levels: a first optimisation, migration of agents (representing services) which are distributed in a decentralised peer-to-peer network, operating continuously in time; this process feeds a second optimisation based on evolutionary computing that operates locally on single peers and is aimed at finding solutions to satisfy locally relevant constraints (p. 1). 
A noteworthy approach to innovation ecosystem is proposed by the Japanese researchers Fukuda and Watanabe (2008), who considered innovation ecosystem at a macro-level. Figure 1 below shows a model for a national innovation ecosystem.

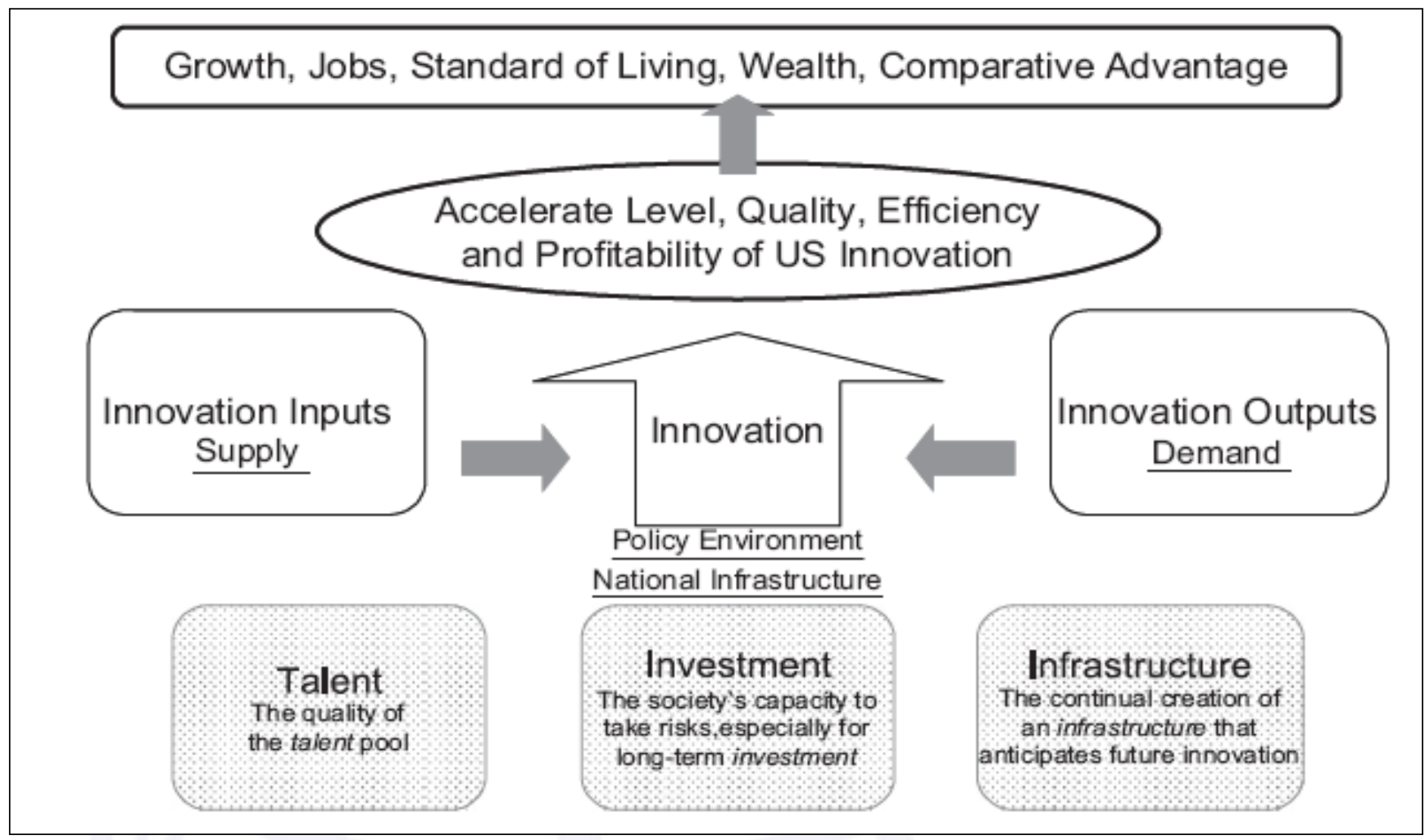

Figure 1 - Scheme of a National Innovation Ecosystem Source: Fukuda e Watanabe (2008)

The last mention of category innovation ecosystem refers to companies such as Google (Google, 2010) and Microsoft (Microsoft, 2010). Both of them, being large agents of innovation network , are noteworthy examples of the development of innovation ecosystems, in and around their environment, and their products. However, this approach appears to be, at least theoretically, challenged by the following fact; it fails to distinguish the essence of natural ecosystems when compared to innovation ecosystems.

The issue in question is that topology of biological ecosystem, haven't got core element in trophic chain. There is a vast number of organisms, though few are key elements responsible for the changes (despite being few, they are not alone). Thus, it is wrongful to affirm that Google and Microsoft create their own ecosystems, and produce projects to expand them. Obviously, in this case 
innovation ecosystem is considered a metaphor and has nothing to do with the theoretical research of what innovation ecosystem is.

In regards to Russian scholars, to summarize, the Russian scientific community does not concern itself with categorizing innovation ecosystem. This term is used by practitioners involved in the process of creating and transferring innovation to the market. The elements of innovation ecosystem, the emerging conditions and possibilities of innovation ecosystem are considered by Kopeykina (2008), Kritov (2008), Rodionov (2010). Said authors declare that the term innovation ecosystem relates to conditions and a set of elements, necessary to drive the mechanisms of the innovation process. However, their perspective is very limited in its nature, i.e. it only applies to the synthesis of professional knowledge and experience, which deal with the creation of start-ups and transfer innovation into practice.

Unfortunately, research in the category innovation ecosystem is neither analyzed nor discussed by the scientific community. Evolutionary approach is presented by Kudrin (1998) and his school of science. Kudrin worked out so called technetic approach, uniting dissipative systems, synergetics, fractality, self-organization, chaos, global evolutionism etc.

According to this approach, many scientific phenomena are considered as analogy of biological cenosis. Kudrin (1998) calls some technological objects (plants, fabrics etc.) as technical cenosis (technocenosis). His followers developed the idea of technological cenosis, consequently separating it into several spheres: business, linguistic, sociology etc (Fufaev, 2006).

Technocenosis is a complex of products and machinery of a certain workshop. Technocenosis involves identifying individuals who belong to a population. There are weak interconnections between the individuals in technocenosis.

One of the principal characteristics of such systems emergence is self-organization. It means, that there is no elements or subsystem which control others or no elements or subsystem which are controlled by other.

Notable is how the process of self-organization occurs. To begin, we shall shed light on the definition and its properties.

Self-organized system appears without any external pressure. Such a system can be stable during both short and/or long periods. The basic problems are the conditions which influence the change of the system's form; the elements in such systems organize themselves in evolving systems, which gain hierarchy of new properties. 
Mechanism of self-organization consists of the following. Random or intended alterations can provoke self-organization, which permit a system to find new states. Said states are unstable, because of disturbances and make a system move towards new attractors (stance). Subsequent progress of the self-organized system can finally reach the optimum stance.

Self-organized system includes a list of features, characterizing such a system. Below, we present Table 1, including a list of said properties coupled with a short description.

\begin{tabular}{|c|c|c|}
\hline \# & Properties & Description \\
\hline 1 & Autonomy & Absence of external control \\
\hline 2 & Dynamics & Evolution and development during the time \\
\hline 3 & Fluctuations & Search of the various parameters and noise \\
\hline 4 & Symmetry emergence & Loosing of liberty and diversity appearance transition from chaos to order \\
\hline 5 & Global order & Emergence from local interactions \\
\hline 6 & Dispersion & Energy use/ non-equilibrium processes \\
\hline 7 & Instability & Nonlinearity/self enforced effects \\
\hline 8 & $\begin{array}{l}\text { Several states of } \\
\text { equilibrium }\end{array}$ & Various types/forms of attractors \\
\hline 9 & Criticality & Edge effect/ Phase transition \\
\hline 10 & System stability & Insensibility to the damages \\
\hline 11 & Complexity & Simultaneous presence of various criteria and purposes \\
\hline 12 & Self determination & Recovery/mechanisms of reproduction \\
\hline 13 & Adaptibility & (functionality/ dependence on external changes) \\
\hline 14 & Hierarchy & The many levels of self-organization \\
\hline 15 & Fractality & $\begin{array}{l}\text { A fractal is "a rough or fragmented geometric shape that can be split into } \\
\text { parts, each of which is (at least approximately) a reduced-size copy of the } \\
\text { whole," }{ }^{11} \text { (a property called self-similarity). }\end{array}$ \\
\hline 16 & Correlation & $\begin{array}{l}\text { Emergence of interdependencies between the elements which were } \\
\text { previously independent }\end{array}$ \\
\hline 17 & $\begin{array}{ll}\text { Self motion } & \text { of the } \\
\text { system } & \text { between } \\
\text { attractors }\end{array}$ & \\
\hline 18 & $\begin{array}{l}\text { Evolution of the system } \\
\text { in organizing form } \\
\text { without any external } \\
\text { influence }\end{array}$ & \\
\hline
\end{tabular}

Table 1 - Properties of self organized systems

Source: Heylighen (2001).

${ }^{1}$ Mandelbrot, B. B. (1982). The fractal geometry of nature. New York: W. H. Freeman.

Revista de Administração e Inovação, São Paulo, v. 7, n. 3, p. 03-20, jul./set. 2010 
A further significant characteristic of the self-organized system is the power law distribution. Using mathematics, it demonstrates the elements of the system according to the rate of definite indicated amount. Calculus is performed using the following formula:

$$
\mathrm{N}(\mathrm{s})=\mathrm{s}-\mathrm{t},
$$

Where:

$$
\begin{gathered}
\mathrm{N}(\mathrm{s})=\text { quantity of events of the amount } \mathrm{s}, \\
\mathrm{t}=\text { characteristic exponent. }
\end{gathered}
$$

The origins of self-organized systems are widely reviewed by Ball (2004), who presented a detailed survey of self-organization's history. His conclusions were based upon a thorough analysis of books and articles dedicated to politics, sociology and physics. The book provides a wide range of multidisciplinary studies, which, in turn, are vital for self-organization research. The history of the social physics and multidisciplinary studies give an account behind the reasons why laws of certain specific phenomena can be transmitted to various sciences, and why it helps to develop science as a whole.

One of the issues explored by Ball (2004) is the World Wide Web. Ball refers to deep analysis, which was carried out by Barabasi (2003). Barabasi considered the limitations concerning selforganization based on the example of a number of social links, the internet, protein chains in cells etc.

His research was undertaken through initiating a theory of mathematical graphs, declaring that not all graphics are random; he believes that there are many networks where new nodes do not join old nodes randomly. Barabasi established regularity of the nodes behavior. He revealed that, contingent upon stochastic motion of the nodes, the newest nodes cannot choose which nodes to join. If not, in certain networks, nodes prefer to join other nodes which have the largest quantity of links, called hubs. However the problem with such behavior is that new nodes will never excel hubs in quantity of links. In reality, Barabasi refuted this hypothesis, illustrating his argument over the internet. If we consider web site search engines, it is widely-known the original was AltaVista. Thus, if we imagine the topology of internet sites, it is clear that AltaVista became the hub among most web sites. 
However, in 1998, Google was established: step by step it became the principal search engine on the internet. Consequently, the fact users consciously choose the best search engine denies the fact that the network is random. Google put its foot in the door and rapidly became successful. Google subsequently proceeded to topple the original search engine, AltaVista, which had previously been credited as the most popular. The results of Barabasi's investigation allowed him to introduce the term free-scale network. Its core characteristic was defined as self-organization. Moreover, free-scale networks are resistant and robust because hubs are connective elements. New nodes join such a network following two principals:

- joining the nodes having the highest number of links;

- joining the nodes which have preferential attachment (i.e. special property of the node which makes it more attractive to others).

The ideas of Barabasi (2003) were developed and applied by American sociologist Ferrary and Granovetter (2009), who discovered the innovation network of Silicon Valley as a network including definite hubs. Their role is played by venture capitalists; the most important participants of the innovation process. According to Ferrary and Granovetter (2009, p. 329), venture capitalists are "the source of robustness of the innovative complex network of Silicon Valley".

Besides venture capitalists, innovation network of Silicon Valley may include other elements shown in Figure 2.

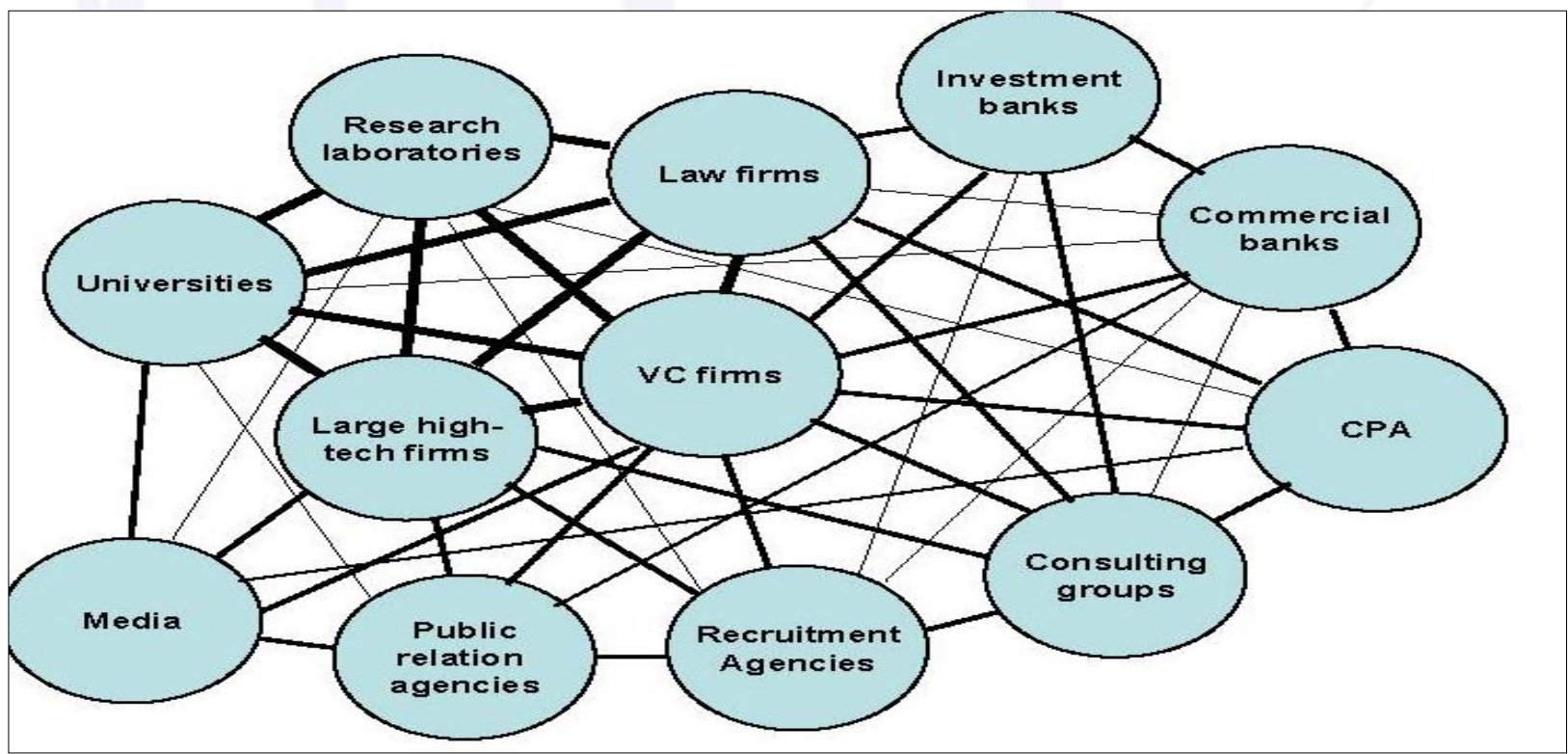

Figure 2 - Innovation Network of Silicon Valley

Source: Ferrary and Granovetter (2009)

Revista de Administração e Inovação, São Paulo, v. 7, n. 3, p. 03-20, jul./set. 2010 
In our opinion, this scheme can be used as a model of innovation ecosystem. However, we find it not wholly sufficient for the explanation of the Silicon Valley phenomena. We believe the aforementioned model must include two further elements:

1. Start-up - a company, resultant from the interactions between innovation network agents.

2. Consumer (as a wider sense) - end-user buyers, large corporations, startups. Nowadays, large corporations generally acquire small, innovative companies which present perspective technologies. In turn, startups provide goods and services from time to time, which can be consumed by end-user buyers, large corporations and by the startups themselves.

Having done the theoretical background survey, we can conclude, that theory of self-organized system has interdisciplinary character. That's why this scientific approach can be applied next to two aspects of innovation ecosystem study.

- Self-organized system properties are inherent to innovation ecosystems and can be revealed through innovation region analysis, where such systems can take place.

- Self-organized system properties can help identify such a system, but do not provide an understanding of an innovation ecosystem's presence. Hence, in our opinion, it is necessary to investigate a definite region and its innovation processes; only then is it possible to speak about innovation ecosystem in the studied region.

Further we will consider our assumptions (hypothesis) in case study.

\section{CASE STUDY}

To conduct a thorough investigation of the aforementioned issues, we chose Silicon Valley as the most innovative region in the world. 
We initially provided correspondence between properties of self-organized systems and characteristics of Silicon Valley's innovation process. The characteristics and the financial data (capital investments) can be seen in Table 2 and Figure 3.

\begin{tabular}{|c|c|c|}
\hline № & Property & Description of the property using Silicon Valley as an example \\
\hline 1 & $\begin{array}{l}\text { Evolution of the system in } \\
\text { organizing form without any } \\
\text { external influence }\end{array}$ & $\begin{array}{l}\text { According to the history of Silicon Valley, the government's role is not } \\
\text { so pivotal, the exemption is program SBIR (Small Business Innovation } \\
\text { Research }^{2} \text { ) and R\&D in the military industry. }\end{array}$ \\
\hline 2 & $\begin{array}{l}\text { Self motion of the system } \\
\text { between attractors }\end{array}$ & $\begin{array}{l}\text { The system actors tend to move to new favorable conditions of the } \\
\text { activity. Each of them and all together make a system to change its } \\
\text { stances. In biology, development by the change of diversity of species } \\
\text { provides attractors shift. By analogy, evolution of different kinds of } \\
\text { activity let the system in a new stance. }\end{array}$ \\
\hline 3 & $\begin{array}{l}\text { Emergence of correlation in time } \\
\text { and space between parameters, } \\
\text { which were independent } \\
\text { previously (correlation) }\end{array}$ & $\begin{array}{l}\text { When the quantity of elements is increasing, there is an increase in } \\
\text { quality interactions between them (if there is a necessity). }\end{array}$ \\
\hline 4 & $\begin{array}{l}\text { Absence of external control } \\
\text { (autonomy) }\end{array}$ & $\begin{array}{l}\text { The state doesn not control Silicon Valley's innovation activity. } \\
\text { Interactions with authority occur in the form of taxation, company } \\
\text { registration fees or in the court. Thus, the governmental influence is } \\
\text { indirect. SBIR being an exception, the acquisition of land around } \\
\text { Stanford University, program of purchasing innovation created in civil } \\
\text { sector by the Ministry of Defence within the program "Commercials- } \\
\text { off-the-shelf"(COTS) }{ }^{3} \text {, presence of NASA in Santa Clara. }\end{array}$ \\
\hline 5 & $\begin{array}{l}\text { Dynamics (evolution and } \\
\text { development during the time) }\end{array}$ & $\begin{array}{l}\text { These properties belong to the majority of dynamic systems. There is } \\
\text { hierarchy too - all system elements interconnect with each over tightly - }\end{array}$ \\
\hline 6 & $\begin{array}{l}\text { Fluctuation (Search of the } \\
\text { different parameters and noise) }\end{array}$ & by means of hubs and centralities. \\
\hline 7 & $\begin{array}{l}\text { Hierarchy (many levels of self- } \\
\text { organization) }\end{array}$ & \\
\hline 8 & $\begin{array}{l}\text { Symmetry emergence (transition } \\
\text { from chaos to order }\end{array}$ & $\begin{array}{l}\text { At the definite moment, by the time when critical mass is reached, the } \\
\text { growth of a system starts. }\end{array}$ \\
\hline 9 & $\begin{array}{l}\text { Global order (emergence from } \\
\text { local interactions) }\end{array}$ & $\begin{array}{l}\text { Silicon Valley emerged in this vein. Local interactions between Stanford } \\
\text { University and Bay Area companies led to the creation of the Research } \\
\text { park, which became a center seen as attractive to other scientists and } \\
\text { entrepreneurs. Thus people and firms approached this region. }\end{array}$ \\
\hline 10 & $\begin{array}{l}\text { Dispersion (energy usage/ non- } \\
\text { equilibrium processes) }\end{array}$ & $\begin{array}{l}\text { Most natural and physical self-organized systems have this property, } \\
\text { hence, we cannot consider this in respect of Silicon Valley's innovation } \\
\text { ecosystem.. }\end{array}$ \\
\hline 11 & $\begin{array}{l}\text { Instability } \\
\text { enforced effects) }\end{array}$ & $\begin{array}{l}\text { Perpetual internal development in the IT industry occurs due to } \\
\text { permanent relocation of elements. It is dependent upon market } \\
\text { conditions, business climate etc. allowing the work force to migrate to } \\
\text { more perspective jobs. Occasionally, engineers become CTOs, even } \\
\text { venture capitalists. IT industry directions die out and new ones take their } \\
\text { place, due to new products and innovative technological ideas. }\end{array}$ \\
\hline 12 & $\begin{array}{l}\text { Several } \\
\text { (Various }\end{array}$ & $\begin{array}{l}\text { Different stages of the development region are defined by certain } \\
\text { directions because of IT-industry activity. For example, the creation of }\end{array}$ \\
\hline & . & \\
\hline
\end{tabular}




\begin{tabular}{|c|c|c|}
\hline & attractors) & $\begin{array}{l}\text { computer chips, to a large extent ,provoked the emergence of many } \\
\text { different companies and marked their modus operandi. The World Wide } \\
\text { Web played a similar role in this process. Many new industries appeared } \\
\text { because of this innovation; web-design, web-services, security, } \\
\text { communications etc. }\end{array}$ \\
\hline 13 & $\begin{array}{l}\text { Criticality (edge effect/ Phase } \\
\text { transition) }\end{array}$ & $\begin{array}{l}\text { This property displays coupled with the change of other system } \\
\text { characteristics. For example, it ensues when certain types of activity } \\
\text { become less attractive and perspective or critical moments appear (the } \\
\text { Internet Bubble or dotcom crash). Creation of radical innovations or } \\
\text { exhaustion of existing technologies has the same change. }\end{array}$ \\
\hline 14 & $\begin{array}{lll}\begin{array}{l}\text { Redundancy } \\
\text { damages }\end{array} & \text { Insensibility } & \text { to } \\
\end{array}$ & $\begin{array}{l}\text { If an element dies out, the system will continue to function. A common } \\
\text { situation in this line of work is that many innovative companies can fold } \\
\text { on a frequent basis.. For example, traditionally venture capitalist's invest } \\
\text { in a portfolio of projects; (s)he choose approximately fifty projects. Ten } \\
\text { of which are invested, of which } 7 \text { of those fail, two reach breakeven } \\
\text { point and one is very successful. Consequently, if the project fails, the } \\
\text { team will seek another project; lost investment is compensated by } \\
\text { consequent successful projects. }\end{array}$ \\
\hline 15 & $\begin{array}{l}\text { Self determination } \\
\text { (Recovery/mechanisms } \\
\text { reproduction) }\end{array}$ & $\begin{array}{l}\text { The best example was the crisis in } 2001 \text {, or the so-called "Internet } \\
\text { Bubble"; volume of financing was fastidiously shortened in } 2001 \text { (see } \\
\text { Fig. } 2 \text { "Financing in Silicon Valley"). It is possible to observe that shock } \\
\text { was the cause of all elements in the system, i.e. it led to a lack of funds, } \\
\text { many technical specialists remained without a job, companies closed etc. } \\
\text { As a result, venture capitalists became more cautious when choosing } \\
\text { projects. After the crisis the region revived and in this current period of } \\
\text { uncertainty remains successful. Remarkably, it happened without any } \\
\text { external intervention. }\end{array}$ \\
\hline 16 & $\begin{array}{l}\text { Adaptability (functionality/ } \\
\text { dependence on external changes) }\end{array}$ & $\begin{array}{l}\text { Independent adaptability to changing conditions of the external } \\
\text { environment. For example, financing for venture investments come not } \\
\text { only from successful projects, but from the economy too. Thus, if the } \\
\text { flow of financing is exaggerated, less investment filters its way to the } \\
\text { venture capital industry. It is not always a bad result; the strongest } \\
\text { projects survive and their level increases. } \\
\text { We would also like to mention that macroeconomic factors take place } \\
\text { here. }\end{array}$ \\
\hline 17 & $\begin{array}{l}\text { Complexity (Simultaneous } \\
\text { presence of different criteria and } \\
\text { purposes) }\end{array}$ & $\begin{array}{l}\text { Silicon Valley's stakeholders have various purposes relating to their } \\
\text { existence. Sometimes these aims can be just the opposite (For example, } \\
\text { venture capitalist prefer to change management of a company where the } \\
\text { founder is CEO at the current moment. At the same time a founder } \\
\text { would like to run a company in the future. Both of them have opposite } \\
\text { interests). Their commonality manifests itself by being completely } \\
\text { interdependent: if no financing is in place, the engineers cannot put the } \\
\text { project into practice. And even in case the project is excellent, but } \\
\text { venture capitalists refused in financing, there is rather smell probability } \\
\text { that the idea will be put in practice. Consequently, elements of the } \\
\text { system can have completely separate criteria from their activity, but they } \\
\text { seek for points of contact to coexist in equilibrium. }\end{array}$ \\
\hline 18 & Fractality & $\begin{array}{l}\text { Fractality function is undertaken by several elements or organizations, } \\
\text { which have similar principles to that of Silicon Valley. If we take into } \\
\text { consideration the connection between science and business and } \\
\text { implemented this in this region, the stakeholders, who have similar } \\
\text { functions, act as fractal units. For instance, commercial or university } \\
\text { business incubators ("Plug\&Play" presented the primary type of } \\
\text { incubator, Stanford Business School, the second). Their activity is } \\
\text { directed to provide a special service (consultancy, access to the internet } \\
\text { etc.) for small companies, or their participation in special events } \\
\text { primarily dedicated to initiating connections between start-ups and }\end{array}$ \\
\hline
\end{tabular}

Revista de Administração e Inovação, São Paulo, v. 7, n. 3, p. 03-20, jul./set. 2010 
Table 2 - Properties of self-organized systems at Silicon Valley

Source: PricewaterhouseCoopers

Figure 3 -Capital Investments in Silicon Valley

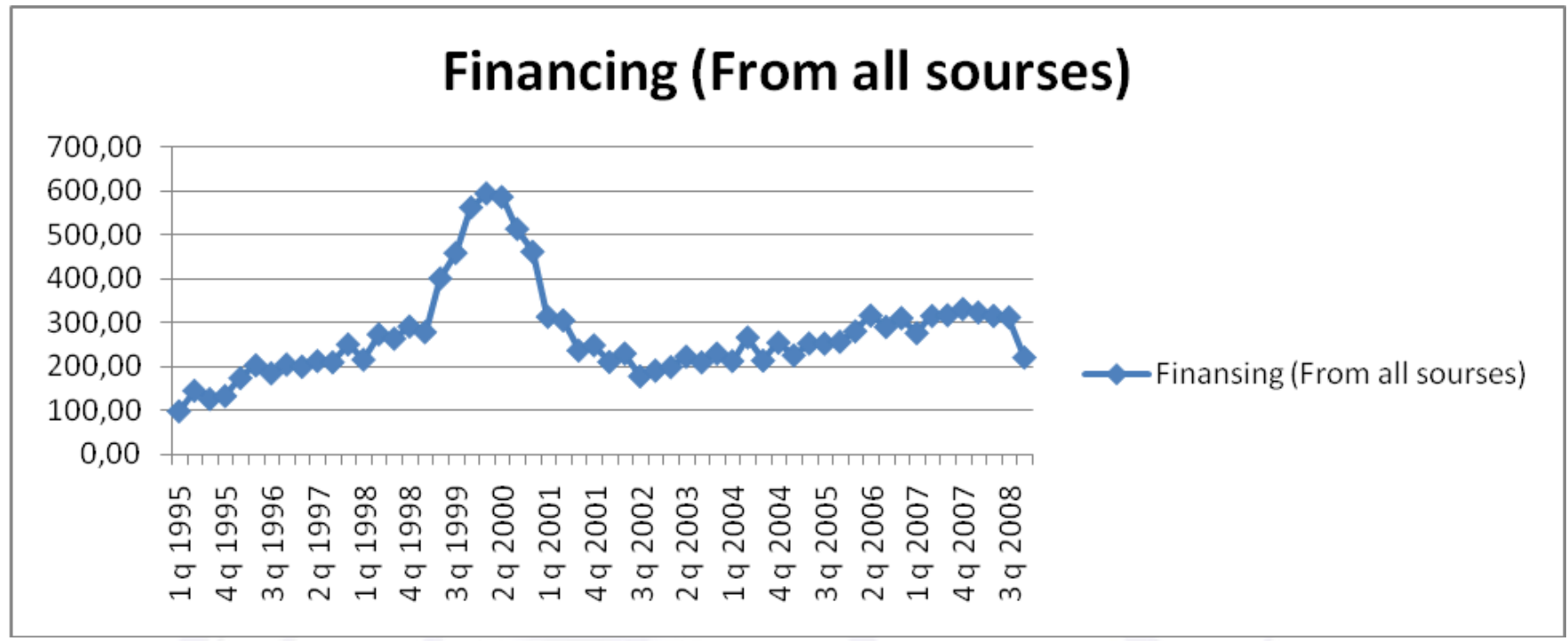

Source: PricewaterhouseCoopers

Based on the correlation between the properties inherent in self-organized systems, we studied whether Silicon Valley, seen as the most innovative region in the world, can be defined as such a system. As we can see from Table 2, almost all of Silicon Valley's factors can be explained from the position of self-organization (15 of 18). Therefore, we can conclude that according to a quantitative description of the object, a hypothesis of whether Silicon Valley can be considered as a self-organized system is carried out.

In our mind, qualitative analysis is the flip side of the coin. As aforementioned, that one of principal mathematician characteristics of self organized system is power law distribution of definite property frequency display. The problem stems from how data should be recorded to evaluate and diagnose the law's presence. Concerning this, we would like to refer to two aforementioned scholars; Kudrin (1998) and Barabasi (2003). Kudrin (1998) discusses the power law distribution applied to the diversity of species, believing that individuals can be classified by the species initially, and ranked after that. This procedure answers the rate of diversity in definite biological or other type of cenosis.

Barabasi (2003) looks at two core points:

- the data related to connections between the elements 
- the possibility of revealing and assessment the stakeholders with the largest quantity of connections.

As a result, the data obtained must be presented on the definite curve. The parameters of the formula, which describe this curve, can shed light on a number of issues. For example, Barabasi (2003), after conducting an abundant amount of research, declared that when indicator S in formula (1) belongs to the range $[2<S<3]$, the exponential growth of the system's elements begins. This output can illustrate one of the self-organized system properties: symmetry.

Symmetry emergence occurs when, at the definite moment, by the time of critical mass accumulation, the exponential growth of a system initiates. The description of this property strongly corresponds to Barabasi's statement. After the elements of the system (or nodes of a free-scale network, according to Barabasi, 2003) accrue sufficient connections, new elements will join the system at an exponential rate.

We believe the above-mentioned property is worthwhile - it concerns the combination of phenomena diagnosed in the creation of innovation regions. Naturally, this is not the sole indicator of innovation ecosystem in a definite region of the world. Previously, we had undertaken research of factors or conditions which make Silicon Valley so attractive to people and to venture capital. Above all, these factors can be considered necessary prerequisites for the emergence of innovation ecosystem. We interviewed residents of Silicon Valley, asking various questions (see Appendix 1). As a result we noted several conditions that nearly all the interviewees mentioned. In Yakovleva (2009-1) we have already extensively discussed these conditions. We classified the factors into two groups: basic and additional conditions. These factors are again presented in Table 3 - they are essential for the current research.

\begin{tabular}{l|l}
\hline \multicolumn{1}{c|}{ Basic conditions } & \multicolumn{1}{c}{ Additional conditions } \\
\hline Venture industry and all innovation network participants : & Cultural aspects: \\
- Large Universities & - people diversty \\
- Venture capitalists & - multiculture \\
- highly educated workforce etc. & - possibility of interesting leisure \\
& - liberal lifestyle \\
\hline Infrastructure (physical and human) & - professional communities, networking \\
\hline - & Geographic location \\
\hline Time & \\
\hline Vicinity of all innovation network participants & Small business support \\
\hline Entrepreneurship: & \\
\hline
\end{tabular}




\begin{tabular}{l|l}
\hline - environment, climate, culture, attitude to companies failure & \\
\hline The system of material incentives for workers & \\
\hline & World center of Product Management \\
\hline Critical mass of talented people & Authority in the world \\
\hline "Success stories" & \\
\hline Market demand & \\
\hline Concentration on the advantages & \\
\hline Low and taxation & \\
\hline Free entrepreneurship and low state financial help & \\
\hline
\end{tabular}

Table 3 - Basic and additional conditions for the emergence of innovation ecosystem

Source: Yakovleva (2010)

To conclude this study, we would like to define the possible directions of self-organization application. Hence, we present our findings below.

\section{RESULTS AND CONCLUSIONS}

The beginning of this study defined various hypothesis relating to self-organization, the impossibility of NIS to satisfy the needs of all the system elements. As an alternative, we mentioned innovation ecosystem as a bottom-up organized system, whose principal feature is self-organization. Therefore, we conclude self-organization as a key feature, and can be utilized as follows:

1. We established the properties inherent in self-organized systems. By describing these characteristics using the example of Silicon Valley, we can assert that if these properties correspond to a definite region, it is possible that self-organized system's can emerge. Within the framework of this article self-organized system is oriented towards innovation process. In this case we can make a mention of innovation ecosystem - a category which is defined by a selforganized system, where due to interaction between its elements directed to exchange of information, financial and other kinds of resources the aim of creation and commercialization of innovations and also sustainable development of present system is attained.

2. Besides the presence of properties defining self-organized systems, there are certain core factors which allow a region to be an innovative ecosystem. These factors were divided into two groups: basic and additional conditions. Moreover, it must not be forgotten the fact that ecosystem is characterized by its connections. Therefore, there must not only exist all the necessary elements 
in the system, but they must also be connected among themselves. By accumulating a critical mass of the connections, the exponential growth of the elements in the system begins.

3. Studing the laws of self-organization and revealing a list of the conditions required for such system emergence, can help to decide such a problem as the possibility of diagnosis, and possible creation of innovation ecosystem in a definite region of the world. The process of allowing the growth of innovation ecosystem includes the choice of two alternatives:

4. expecting the moment when the conditions form and emerge;

5. facilitation of the conditions' creation.

6. The presence of special conditions, and what that brings to the emergence of an innovation ecosystem. This system permits the venture capital industry to grow: merge all the necessary elements; Universities, venture capitalists, service providers, HR agencies, consulting companies, media, research laboratories, start-ups etc. These interconnections empower the venture capital industry to function as an assembly line. In turn, it creates perpetual demand for innovations, and consequently, the will to commercialize innovation.

\section{REFERENCES}

Arthur, W. B. (1994). Increasing returns and path dependence in the economy. Ann Arbor: The University of Michigan.

Arthur, W. B. (1989). Competing technologies, increasing returns, and lock-in by historical events. The Economic Journal, 99(394), 116-131.

Ayres, R. U. (2004). On the life cycle metaphor: where ecology and economics diverge. Ecological Economics, 48(4), 425- 438

Barabasi, A. L. (2003). Linked: how everything is connected to everything else and what it means. Cambridge: Plume.

Ball, P. (2004). Critical mass: how one thing leads to another. New York: Farrar, Straus and Giroux. 
Briscoe, G., \& De Wilde, P. (2009). Digital ecosystems: evolving service-oriented architectures. Retrieved July 01, 2010, from http://arxiv.org/abs/0712.4102.

David, P. A. (1985). Clio and the Economics of QWERTY. The American Economic Review, 75(2), 332-337.

Ferrary, M., \& Granovetter, M. The role of venture capital firms in Silicon Valley's complex innovation network. Economy and Society, 38(2), 326-359.

Freeman, C. (1987). Technology and economic performance: lessons from Japan. London: Pinter.

Fufaev, V. V. (2006). Economical cenosis of organizations. Moscow: Center of System Research.

Fukuda, K., \& Watanabe, C. (2008). Japanese and US perspectives on the national innovation ecosystem. Technology in Society, 30(1), 49-63

Google. (n.d.). General search. Retrieved June 06, 2010, from http://www.hbr-russia.ru/issue/39/269/.

Heylighen, F. (2001). The science of self-organization and adaptivity. Brussels: Free University of Brussels.

Hayek, F. A. (1992). Harmful self-assurance: the mistakes of socialism. Moscow: News.

Kopeikina, L. (2008). Ecosystem for venture business. The Angel Investor, 1(2), 10-13.

Kritov, V. (2008). Ecosystem of Silicon Valley. The Angel Investor, 4(10), 47-53.

Kudrin, B. I. (1998). Technetics: philosophy of technique new paradigm (the third scientific picture of the world). Tomsk: Tomsk State University.

Lundvall, B-Å. (Ed.) (1992). National innovation systems: towards a theory of innovation and interactive learning. London: Pinter.

Metcalfe, S. (1995). The economic foundations of technology policy: equilibrium and evolutionary perspectives. In P. Stoneman (Ed.), Handbook of the economics of innovation and technological change (pp. 408-422). Cambridge: Blackwell.

Microsoft. (n.d.). General search. Retrieved June 15, 2010, from http://www.microsoft.com/canada/media/ecosystem.mspx.

Moore, J. F. (1997). The death of competition: leadership and strategy in the age of business ecosystems. New York: Harper Business. 
Nelson, R. R. (Ed.) (1993). National innovation systems: a comparative analysis. New York: Oxford University Press.

PricewaterhouseCoopers. (n.d.). MoneyTree ${ }^{\mathrm{TM}}$ Report. Retrieved June 15, 2010, from https://www.pwcmoneytree.com/MTPublic/ns/nav.jsp?page=resource.

Rodionov. Retrieved May 01, 2010, from http://www.nicor.ru/philosophy.html\%Rodionov.

Van der Bergh, J. (2003). Evolutionary analysis of economic growth, environment and resources. In R. U. Ayres, D. Simpson, \& M. A. Toman (Eds.), Scarcity and growth in the new millennium (pp. 177-197). Baltimore: Johns Hopkins University Press.

Yakovleva, A. (2010). Sillicon Valley in Russia: is it possible? Management of Innovation, 3(11), 186201.

Yakovleva, A. (2009). Perspectives for innovation development in Russia [CD-ROM]. Proceedings of The Conference of Global Business and Technology Association, 11. New York: GBATA.

\section{AUTO-ORGANIZAÇÃO COMO FERRAMENTA PARA DIAGNOSE EM ECOSISTEMAS INOVADORES}

\section{RESUMO}

Vários estudos tem sido realizados para identificar mecanismos inovadores de desenvolvimento com êxito de diferentes regiões inovadoras. O objetivo da presente pesquisa é dar contribuições ao entendimento deste problema considerando a teoria da auto-organização de sistemas e as principais propriedades de redes livres. Usando o exemplo do Silicon Valley (USA), pode-se estudá-lo como um sistema auto-organizado, e assim determinar que peculiaridades, princípios de funcionamento e leis deveriam estar disponíveis para uso em ecosistemas inovadores. A auto-organização como característica principal de ecosistemas inovadores junto com os pré-requisitos para a inovação suporta o crescimento do Silicon Valley e poderia ser recomendado como um arquétipo para ser usado em diferentes países e regiões do mundo.

Palavras chave: Mecanismos inovadores; Auto-organização de sistemas; Ecosistemas inovadores.

Data do recebimento do artigo: 15/07/2010

Data do aceite de publicação: 25/09/2010

Revista de Administração e Inovação, São Paulo, v. 7, n. 3, p. 03-20, jul./set. 2010 